Indalecio Morán Judith Bellapart Alessandra Vari Jordi Mancebo

\section{Erratum to: Heat and moisture exchangers and heated humidifiers in acute lung injury/ acute respiratory distress syndrome patients. Effects on respiratory mechanics and gas exchange}

Published online: 24 May 2012

(C) Copyright jointly held by Springer and ESICM 2012

The online version of the original article can be found under doi:10.1007/s00134-006-0073-1.

I. Morán · J. Bellapart · A. Vari · J. Mancebo $(\bullet)$

Servei de Medicina Intensiva, Hospital de la Santa Creu i Sant Pau, Universitat Autònoma de Barcelona (UAB),

Sant Quintí, 89, 08041 Barcelona, Spain

e-mail: jmancebo@santpau.es

Tel.: +34-93-2919187

Fax: +34-93-2919280

\section{Erratum to: Intensive Care Med (2006) 32:524-531} DOI 10.1007/s00134-006-0073-1

The authors' address has been corrected to reflect their affiliation to Universitat Autònoma de Barcelona (UAB). 